
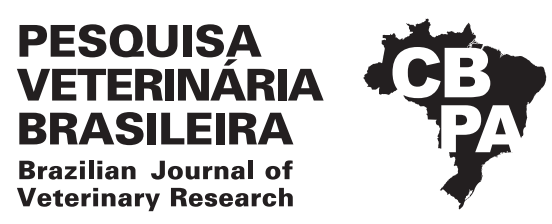

Pesq. Vet. Bras. 38(7):1300-1306, julho 2018 DOI: 10.1590/1678-5150-PVB-5211

Original Article

ISSN 0100-736X (Print)

ISSN 1678-5150 (Online)

\title{
Comparison of three diagnostic methods for Salmonella enterica serovars detection in chicken rinse ${ }^{1}$
}

\author{
Isadora M.O. Corrêa ${ }^{2 *}$, Larissa Q. Pereira², Isabella G.O. Silva², Rafaela Altarugioº \\ Bruna D. Smaniotto ${ }^{2}$, Tarcísio M. Silva², Adriano S. Okamoto ${ }^{2}$ \\ and Raphael L. Andreatti Filho ${ }^{2}$
}

\begin{abstract}
Corrêa I.M.O., Pereira L.Q., Silva I.G.O, Altarugio R., Smaniotto B.D., Silva T.M., Okamoto A.S. \& Andreatti Filho R.L. 2018. Comparison of three diagnostic methods for Salmonella enterica serovars detection in chicken rinse. Pesquisa Veterinária Brasileira 38(7):1300-1306. Laboratório de Patologia Aviária, Departamento de Clínica Veterinária, Faculdade de Medicina Veterinária e Zootecnia, Universidade Estadual Paulista, Botucatu, São Paulo, SP 18618-970, Brazil.E-mail: isamainieri@yahoo.com.br

Salmonella detection is a key point in food safety testing, because of the frequent association of this pathogen with food poisoning in humans. The standard bacteriological tests currently used for Salmonella-detection are time-consuming; therefore, there is a need to develop alternative methods to accelerate the detection. In order to accelerate Salmonella diagnosis, we used the immunomagnetic separation assay associated with bacteriophage P22 for the rapid detection of the following Salmonella serovars in chicken rinses of drumsticks, artificially contaminated with 5, 10, and $100 \mathrm{CFU} / 25 \mathrm{~mL}$ of bacteria: Salmonella enterica subsp. enterica serovar Heidelberg ( $S$. Heidelberg), Salmonella enterica subsp. enterica serovar Enteritidis (S. Enteritidis) and Salmonella enterica subsp. enterica serovar Typhimurium (S. Typhimurium). The efficiency of the technique, represented by the time required for detection of positive and negative samples, was compared with that of the standard diagnostic tests used for this pathogen, the bacteriological assay and the polymerase chain reaction (PCR)-based test. This study confirmed the ability of the bacteriophage-associated immunomagnetic separation assay to identify $99.6 \%$ of Salmonella-positive samples of the three serovars tested. In contrast, the bacteriological assay and PCR-based test detected $95.1 \%$ and $98.5 \%$ of the Salmonella-positive samples respectively.
\end{abstract}

INDEX TERMS: Diagnostic, Salmonella enterica, serovars, chicken rinse, phage P22, Salmonella Heidelberg, Salmonella Typhimurium, Salmonella Enteritidis, immunomagnetic.

RESUMO.- [Comparação de três métodos diagnósticos para detecção de Salmonella enterica em lavados de carcaça de frango.] A detecção de Salmonella é um ponto crucial para a segurança alimentar, devido a frequente associação deste patógeno com infecções alimentares em humanos. 0 método padrão para detecção de Salmonella é o bacteriológico, mas o tempo requerido para o processamento das amostras e o diagnóstico final é longo, por isso existe a necessidade de desenvolvimento de métodos alternativos que visem acelerar esta etapa. Para

\footnotetext{
${ }^{1}$ Received on May 20, 2017.

Accepted for publication on June 20, 2017.

${ }^{2}$ Laboratório de Patologia Aviária, Departamento de Clínica Veterinária, Faculdade de Medicina Veterinária e Zootecnia, Universidade Estadual Paulista (Unesp), Botucatu, São Paulo, SP 18618-970, Brazil. *Corresponding author: isamainieri@yahoo.com.br
}

isto utilizamos a separação imunomagnética associada ao bacteriófago P22 como técnica de detecção rápida para os seguintes sorovares de Salmonella: Salmonella enterica subsp. enterica sorovar Heidelberg ( $S$. Heidelberg), Salmonella enterica subsp. enterica sorovar Enteritidis ( $S$. Enteritidis) e Salmonella enterica subsp. enterica sorovar Typhimurium ( $S$. Typhimurium), os quais foram inoculados artificialmente em lavados de sobre-coxas de frango nas seguintes concentrações: 5, 10 e 100 UFC $/ 25 \mathrm{~mL}$. A eficiência da técnica, representada pelo tempo requerido para detecção de amostras positivas ou negativas, foi comparado com os testes rotineiramente utilizados para detecção de Salmonella, o exame bacteriológico e a reação em cadeia da polimerase (PCR). Este estudo confirmou a capacidade do teste de separação imunomagnética associado a bacteriófago, o qual identificou $99,6 \%$ das amostras 
positivas para Salmonella, dos três sorovares testados. Já o bacteriológico e PCR identificaram respectivamente $95,1 \%$ e $98,5 \%$ das amostras positivas.

TERMOS DE INDEXAÇÃO: Diagnósticos, Salmonella enterica, carcaça de frango, fago P22, Salmonella Heidelberg, Salmonella Typhimurium, Salmonella Enteritidis, bacteriológico, imunomagnética, frangos.

\section{INTRODUCTION}

Non-typhoid Salmonella, listed as one of the main pathogens involved in foodborne diseases, is the leading cause of hospitalization (35\%) and death (28\%) of patients affected by consumption of contaminated products in the United States (Scallan et al. 2011). Of the 2,541 Salmonella enterica serovars identified until now, Salmonella enterica subsp. enterica serovar Enteritidis (S. Enteritidis), S. enterica subsp. enterica serovar Typhimurium (S. Typhimurium), and S. enterica subsp. enterica serovar Heidelberg ( $S$. Heidelberg) are among the ten serovars most frequently isolated from human sources in the United States. S. Enteritidis and S. Typhimurium account for $27.6 \%$ of all laboratory-confirmed cases (CDC 2014). In the state of Washington (USA), the percentage of Salmonella-positive meat samples was $3 \%$, and poultry meat had the highest contamination rate (4.2\%) (Zhao et al. 2001). In Colombia the prevalence of Salmonella-contaminated broiler chicken was $27 \%$ in a multi-factorial study involving the analysis of several factors, including the type of poultry production and storage conditions (Donado-Godoy et al. 2012). In Brazil, the Salmonella prevalence in poultry carcasses was $2.7 \%$ and the major serotypes identified were $S$. Enteritidis, $S$. Infantis, $S$. Typhimurium, and $S$. Heidelberg (Medeiros et al. 2011). In northeastern Brazil $9.6 \%$ of chicken carcasses evaluated microbiologically were positive for this pathogen (Duarte et al. 2009). In the state of São Paulo, a study reported $2.5 \%$ of samples positive for Salmonella in chicken carcasses industrially processed in 2008 (Tessari et al. 2008), whereas another survey conducted in 2000, in the same state, found $32 \%$ samples positive for Salmonella in frozen chicken carcasses (Santos et al. 2000).

Historically, Salmonella is widespread in the poultry farms of Brazil, particularly in the eggs, chicken, and the environment (Andreatti Filho et al. 2001). The bacteriological method recommended for the diagnosis of Salmonella spp. is labor intensive and requires 4 to 5 days to obtain presumptive positive or negative results. Therefore, the development of rapid tests is essential for the diagnosis and the control of Salmonella spp. (Alcocer \& Oliveira 2003). Microbiological diagnosis of pathogens to determine food safety has remained in use for many years, because it is an established and effective technique, although time-consuming. Molecular techniques, such as PCR, are being used routinely in laboratories with bacteriological techniques to provide a more accurate diagnosis in a shorter period of time (Andrade et al. 2010). However, it is essential to invest in research efforts to improve or develop rapid tests for the detection of Salmonella spp. in poultry meat to minimize the risks of consumers contracting salmonellosis (Eijkelkamp et al. 2009).

Alternatively, bacteriophages have been identified as a promising agent for detection of bacterial pathogens. Beneficial attributes of bacteriophages as diagnostic reagents for pathogens include high-capacity multiplication, specificity for bacterial agents, lack of toxicity, and ease of being found in nature (García \& López 2002).

We evaluated the efficiency of the immunomagnetic separation assay associated with a bacteriophage, using the knowledge of phage P22, for detection of $S$. Enteritidis, $S$. Typhimurium, and $S$. Heidelberg in chicken rinse. This assay was compared with two other diagnostic tests, the bacteriological assay and the PCR-based test, to determine the ability of each method in detecting positive and negative samples, as well as the time required to obtain the results. Therefore, we artificially contaminated chicken drumsticks with three different dosages of bacterial inoculum, prior to testing the efficiency of the three diagnostic methods.

\section{MATERIALS AND METHODS}

Bacterial samples. A total of 30 samples of each bacterial serovar, namely Salmonella enterica subsp. enterica serovar Heidelberg (S. Heidelberg), Salmonella enterica subsp. enterica serovar Enteritidis (S. Enteritidis) and Salmonella enterica subsp. enterica serovar Typhimurium ( $S$. Typhimurium) were used to artificially contaminate chicken rinses of drumsticks. The drumsticks were subjected to conventional bacteriological analyses, including biochemical and serological screening tests, the bacteriophage-associated immunomagnetic separation assay, and PCR-based test. The bacterial strains were previously isolated from poultry source and stocked in the bacterial collection of the Avian Pathology Laboratory of FMVZ/UNESP, Sao Paulo State University, Sao Paulo, Brazil. The strains were stored in nutrient agar (NA; HiMedia, Mumbai, India) at $4{ }^{\circ} \mathrm{C}$ and were previously serotyped by the Adolfo Lutz Institute, SP, Sao Paulo State, Brazil.

Bacterial inoculum preparation. To determine the inoculum size in colony forming unit $(\mathrm{CFU} / \mathrm{mL})$, we used the spread-plate technique, which comprises serial dilutions and plating on solid agar. Pure colonies in the stationary growth phase were added to $10 \mathrm{~mL}$ of tryptone soya broth (TSB; HiMedia, Mumbai, India). Then serial dilutions were performed in phosphate buffered saline (PBS) to $10^{-5}$ and plated onto brilliant green agar (BGA; Sigma-Aldrich, St. Louis, MO, USA). After bacteriological incubation for 24 hours at $37^{\circ} \mathrm{C}$, colony counting was performed. During this period, the inoculum was maintained at $4{ }^{\circ} \mathrm{C}$ to prevent bacteria from multiplying. Then the bacterial inoculum was diluted to achieve the following concentrations: 5,10 , and $100 \mathrm{CFU} / 25 \mathrm{~mL}$, and a new colony count was carried out as described above.

Preparation of samples. Poultry drumsticks, obtained from a chain supermarket in Botucatu/Sao Paulo, were weighed using an analytical balance and segregated into portions of $25 \mathrm{~g}$. The $25 \mathrm{~g}$ slices were transferred into a sterile stomacher bag, with full filter, and $225 \mathrm{~mL}$ of TSB was added to mix the samples for 2 minutes in a homogenizer type stomacher. Then, $25 \mathrm{~mL}$-aliquots of the homogenate were put in a $45 \mathrm{~mL}$-sterile-falcon tube and inoculated with Salmonella. For each bacterial sample prepared, three concentrations - namely 5,10 and $100 \mathrm{CFU}$ - were inoculated in $25 \mathrm{~mL}$ of chicken rinse. For the three diagnostics tests, the bacteriophage-associated immunomagnetic separation assay, the bacteriological assay, and the PCR-based test, 90 bacterial analyses were performed per serovar (including the three inoculum concentrations), resulting in 270 tests for Salmonella in total. Each chicken rinse used for the assays was screened for Salmonella spp. by using bacteriological assays, to ensure absence of any prior contamination with this pathogen until the inoculum preparation. 
Enrichment step. This step was common to the three diagnostic tests performed and consisted of addition of $25 \mathrm{~mL}$ of previously inoculated chicken rinse to $250 \mathrm{~mL}$ of TSB broth, supplemented with $20 \mu \mathrm{g} / \mathrm{mL}$ novobiocin (Inlab, Diadema/SP, Brazil) and incubated for 16 hours at $37^{\circ} \mathrm{C}$.

Control samples. In all analyses, positive control samples of $S$. Typhimurium pure culture in TSB broth were included. The negative controls used were Escherichia coli pure culture in TSB medium and an aliquot of the chicken rinse not inoculated with Salmonella.

Bacteriophage. The virulent bacteriophage P22 (ATCC 19585B1) was used for the immunomagnetic separation assay (described below). Prior to each test, the phage was amplified. A pure culture of $S$. Typhimurium was grown in TSB $2 \mathrm{x}$. Of this broth, $2 \mathrm{~mL}$ was mixed with $1 \mathrm{~mL}$ of the bacteriophage in stationary phase and $5 \mathrm{~mL}$ of TSB, followed by 12 hours of incubation at $37^{\circ} \mathrm{C}$. Afterwards, centrifugation was performed for 10 minutes at $7,000 \times g$, the supernatant was filtered with a minisart $0.22 \mu \mathrm{m}$ syringe (Intec Sartorius, Goettingen, Germany), and the resulting solution was stored at $4^{\circ} \mathrm{C}$. The amplified phage was quantified by the plate assay and serially diluted to $10^{-10}$. Then $100 \mu \mathrm{L}$ of the diluted phage was added to $300 \mu \mathrm{L}$ of its susceptible bacterial host, in this case a sample of $S$. Typhimurium in an exponential phase of growth. After 15 minutes of this pre-adsorption step the bacteriophage/bacteria suspension was added to tubes containing $5 \mathrm{~mL}$ of soybean casein digest soft agar (TSA; HiMedia, Mumbai, India) and was put on heated TSA plates. After $18-24$ hours of incubation at $37^{\circ} \mathrm{C}$, the viral plaques were counted and the phage concentration was determined in the sample (Panec \& Katz 2006, Andreatti Filho et al. 2007).

Immunomagnetic separation associated with bacteriophage. This test consists of four distinct phases: capture, binding and amplification, incubation, and detection (described below) (Favrin et al. 2001).

Capture. Aliquots of $1 \mathrm{~mL}$ of the enrichment broth were added to wells with $20 \mu \mathrm{L}$ of antibody magnetic beads (Dynabeads ${ }^{\circledR}$ anti-Salmonella; AppliedBiosystemsTM, Foster City, CA, USA). Then the wells were subjected to the rotating mixer for 30 minutes (Dynal ${ }^{\circledR}$ MX4 mixer, Invitrogen, Oslo, Norway). Subsequently, the samples were transferred to a magnetic particle separator (Dynal Magnetic Particle Concentrator ${ }^{\circledR}$ MPC-S, Invitrogen, Oslo, Norway) for 3 minutes to separate the beads from the enrichment broth. The supernatant was aspirated and discarded, and the magnetic beads were washed twice in PBS buffer Tween-80 (PBST; (100mL 10xPBS, 1.37mM NaCl, $27 \mathrm{mM} \mathrm{KCl}_{10} 100 \mathrm{mM} \mathrm{Na}_{2} \mathrm{HPO}_{4}, 20 \mathrm{mM} \mathrm{KH}_{2} \mathrm{PO}_{4}, 900 \mathrm{~mL}$ of sterile distilled water and $5 \mathrm{~mL}$ of Tween 80 ) at $0.1 \%$ and re-suspended in $250 \mu \mathrm{L}$ TSB.

Attachment and amplification. Hundred microliters of bacteriophage P22 was added to the wells, with approximately $10^{8} \mathrm{PFU} / \mathrm{mL}$ (plaque-forming unit), followed by an incubation for 10 minutes at $37^{\circ} \mathrm{C}$. If the sample was positive, the bacteriophage will attach to the bacteria captured on the beads. After incubation the samples were placed on MPC-S ${ }^{\circledR}$ and washed with PBST solution. This step is necessary to remove the unbound phage. The beads were suspended in $100 \mu \mathrm{L}$ of TSB and incubated for 30 minutes at $37^{\circ} \mathrm{C}$ to release the phage progeny.

Incubation and detection. The supernatant was added into a new microtube, containing $1 \mathrm{~mL}$ of the signal amplifying cells (SAC), which is a pure culture of $S$. Typhimurium cultured in TSB broth with 20 hours of incubation. The optical density of the broth was adjusted to 0.075 at $600 \mathrm{~nm}$ with a spectrophotometer (GeneQuantTMpro, Amersham Biosciences, Buckinghamshire, England, UK). SAC are essential for recovery of the phage progeny, because the addition of healthy cells of Salmonella will improve the bacteriophage cell lysis and increase their lytic power.
In this last stage, the samples were incubated for $2 \mathrm{~h}$ at $37^{\circ} \mathrm{C}$. In the positive samples we were able to detect the expression of lysis, since the phage was bound on beads impregnated with Salmonella and expressed the lytic cycle upon being exposed to a new bacterial culture (SAC).

For the final step, $1 \mathrm{~mL}$ of the broth was transferred to a disposable plastic cuvette and the optical density was measured in a spectrophotometer. The samples with an optical density $70 \%$ lower than the mean values of the negative control samples were considered to be positive. These values have been established in studies by other researchers (Favrin et al. 2001). In summary, positive samples will show a decrease in optical density. Moreover, negative samples will show a high optical density, since there are no Salmonella cells linked to the beads. Therefore, the phage will not bind to the magnetic particles and will be removed during washing. Thus, when SAC was added, there were no bacteriophages able to combat the new Salmonella cells present in the SAC.

Bacteriological analysis. Of the pre-enrichment broth, $1 \mathrm{~mL}$ was added to tetrathionate broth (Acumedia, Lansing, Michigan, USA), supplemented with $200 \mu \mathrm{L}$ of iodine solution and $100 \mu \mathrm{L}$ of bright green. Furthermore, $100 \mu \mathrm{L}$ of the pre-enrichment broth was added to Rappaport-Vassiliadis broth (Acumedia, Lansing, Michigan, USA) and incubated for 24 hours at $41^{\circ} \mathrm{C}$. The selective enrichment broths were plated on BGA and xylose-lysine-deoxycholate agar (XLD; Sigma-Aldrich, St. Louis, MO, USA) and incubated at $37^{\circ} \mathrm{C}$ for 24 hours. The colonies showing a morphology similar to Salmonella spp. were selected to perform a biochemical screening, consisting of the following assays: triple sugar iron agar (TSI; HiMedia, Mumbai, India), lysine iron agar (LIA; Difco, Maryland, United States), urea broth (Difco, Maryland, United States), sulfide indole motility (SIM; HiMedia, Mumbai, India), and Simmon's citrate agar (Difco, Maryland, United States). Subsequently, the agglutination test was performed with polyvalent antiserum "O" for Salmonella (Probac do Brasil, Sao Paulo, SP, Brazil). Colonies with morphology similar to that of Salmonella, a compatible biochemical screening, as well as a positive reaction in the agglutination test with polyvalent antiserum "O", were deemed to be positive.

DNA extraction. The samples used for PCR were obtained from the selective enrichment step for Salmonella during processing for bacteriological analysis. Of the Rappaport-Vassiliadis broth, $1 \mathrm{~mL}$ was placed into $1.5 \mathrm{~mL}$-microtubes free of DNase, RNase and pyrogens, and frozen at $-20^{\circ} \mathrm{C}$ for further analysis. DNA samples were extracted by heat treatment. The protocol consisted of three washes with $1 \mathrm{~mL}$ of PBS, followed by centrifugation at $8,000 \times \mathrm{g}$ for 5 minutes at $10^{\circ} \mathrm{C}$. After the last wash the pellet was resuspended in $600 \mu \mathrm{L}$ of TE (10 mM Tris-HCl and 1 mM EDTA, pH 8.0) and heated in a water bath at $95^{\circ} \mathrm{C}$ for 10 minutes. Finally, the sample was centrifuged at $5,900 \times g$ for 5 minutes at $10^{\circ} \mathrm{C}$. Of the supernatant $200 \mu \mathrm{L}$ was collected and stored at $-20^{\circ} \mathrm{C}$ (Fadl et al. 1995 , Andreatti Filho et al. 2011).

PCR technique. Primers specific for the invA gene were used for the reaction (Fw: 5'-TTGTTACGGCTATTTTGACCA-3'; Rv: 5'-CTGACTGCTACCTTGCTGATG-3') (Swamy et al. 1996) at a concentration of $20 \mathrm{pmol} / \mu \mathrm{L}$. A final volume of $25 \mu \mathrm{L}$ was used for the amplification, containing $5 \mu \mathrm{L}$ of each sample, $1 \mu \mathrm{L}$ of each primer, $12.5 \mu \mathrm{L}$ of Go Taq ${ }^{\circledR}$ Green Master Mix (Promega, Madison, USA), and $5.5 \mu \mathrm{L}$ of ultrapure water. The mixture was processed in a thermocycler (Eppendorf AG Mastercycler Gradient): 5 minutes $94^{\circ} \mathrm{C}, 35$ cycles of amplification ( 30 seconds at $94^{\circ} \mathrm{C}, 30$ seconds at $60^{\circ} \mathrm{C}$, and 30 seconds at $72^{\circ} \mathrm{C}$ ), followed by a final extension for 4 minutes at $72^{\circ} \mathrm{C}$ (Marietto-Gonçalves et al. 2011). The PCR products 
were analyzed on a 1.5\% agarose gel stained with GelRed (Biotium) and visualized in a transilluminator. The amplification products were considered positive when the resulting band presented the expected size of $521 \mathrm{bp}$.

Statistical analysis. The association test of Goodman was used, complemented by multiple comparisons between binomial populations (Goodman 1964), at the 5\% level of significance.

\section{RESULTS}

\section{Salmonella Heidelberg}

All samples of this serovar were deemed positive by the bacteriophage-associated immunomagnetic separation assay and by PCR. In the bacteriological test 81 samples (90\%) tested positive. The results for each inoculation concentration are shown in Table 1.

\section{Salmonella Enteritidis}

The chicken rinses drumsticks, artificially contaminated with $S$. Enteritidis, showed the same pattern in the analysis by PCR and the bacteriophage-associated immunomagnetic separation assay. In total, 89 samples tested positive (98.8\%) in both tests, while the only negative sample in both tests corresponded to the sample with inoculum concentration of $5 \mathrm{CFU} / 25 \mathrm{~mL}$. However, in the bacteriological test 88 samples were deemed positive (97.7\%), with the negative samples corresponding to samples with inoculum concentrations of 5 and $100 \mathrm{CFU} / 25 \mathrm{~mL}$ (Table 2).

\section{Salmonella Typhimurium}

In the experiment with $S$. Typhimurium, we found a higher detection level for positive samples when performing the bacteriophage-associated immunomagnetic separation assay,

Table 1. Samples positive for Salmonella Heidelberg in the bacteriophage-associated immunomagnetic separation assay, the bacteriological test, and PCR-based test, using three inoculum concentrations to contaminate poultry chicken rinse artificially

\begin{tabular}{lccc}
\hline \multicolumn{1}{c}{ S. Heidelberg } & $\begin{array}{c}\text { Immunomagnetic } \\
\text { separation assay }\end{array}$ & Bacteriological & PCR \\
\hline $5 \mathrm{CFU} / 25 \mathrm{~mL}$ & 30 & 27 & 30 \\
$10 \mathrm{CFU} / 25 \mathrm{~mL}$ & 30 & 25 & 30 \\
$100 \mathrm{CFU} / 25 \mathrm{~mL}$ & 30 & 29 & 30 \\
Positive percentage & $100 \%$ & $90 \%$ & $100 \%$
\end{tabular}

Table 2. Samples positive for Salmonella Enteritidis in the bacteriophage-associated immunomagnetic separation assay, the bacteriological test and PCR-based test, using three inoculum concentrations to contaminate poultry chicken rinse artificially

\begin{tabular}{lccc}
\hline \multicolumn{1}{c}{ S. Enteritidis } & $\begin{array}{c}\text { Immunomagnetic } \\
\text { separation assay }\end{array}$ & Bacteriological & PCR \\
\hline $5 \mathrm{CFU} / 25 \mathrm{~mL}$ & 29 & 29 & 29 \\
$10 \mathrm{CFU} / 25 \mathrm{~mL}$ & 30 & 30 & 30 \\
$100 \mathrm{CFU} / 25 \mathrm{~mL}$ & 30 & 29 & 30 \\
Positive percentage & $98.8 \%$ & $97.7 \%$ & $98.8 \%$
\end{tabular}

detecting the presence of all 90 positive samples (100\%). However, 87 samples tested positive (96.6\%) in the PCR assay, one sample testing negative at an inoculum concentration of $10 \mathrm{CFU} / 25 \mathrm{~mL}$ and other two samples testing negative at an inoculum concentration of $5 \mathrm{CFU} / \mathrm{mL}$. Analyzing the results obtained by the bacteriological test, 88 samples tested positive (97.7\%), with one sample testing negative at an inoculum concentration of $100 \mathrm{CFU} / 25 \mathrm{~mL}$ and the other at an inoculum concentration of $5 \mathrm{CFU} / 25 \mathrm{~mL}$ (Table 3 ).

\section{Diagnostic time}

The methodology that combines the immunomagnetic separation assay with bacteriophage P22 was able to detect the presence of viable cells of Salmonella in chicken rinses within about 19 hours, including the enrichment step (Fig.1). In the bacteriological test, the total time required for the final diagnosis was approximately 88 hours, including the steps of enrichment (16 hours), selective enrichment (24 hours) and plating on solid agars (24 hours), as well as biochemical screening and serology (24 hours). The diagnosis of Salmonella serovars by PCR took approximately 43 hours, including enrichment (16 hours) and selective enrichment

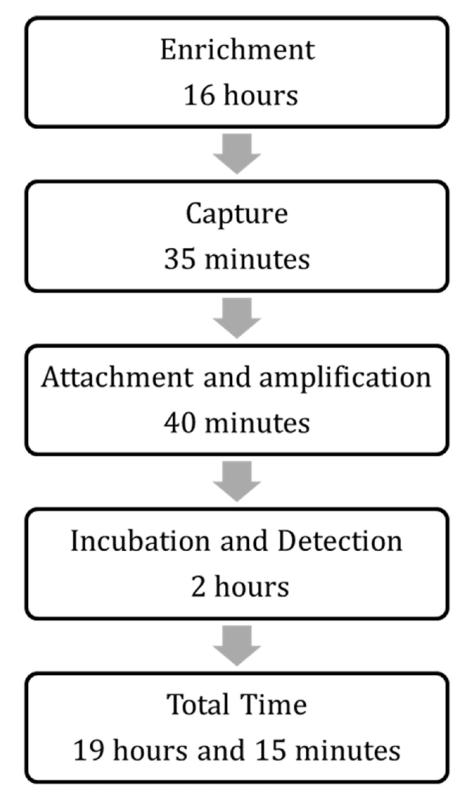

Fig.1. Steps in the bacteriophage-associated immunomagnetic separation assay with their respective time durations and the total time taken for the final diagnosis of Salmonella spp. in chicken rinse.

Table 3. Samples positive for Salmonella Typhimurium in the bacteriophage-associated immunomagnetic separation assay, the bacteriological test, and PCR-based test, using three inoculum concentrations to contaminate poultry chicken rinse artificially

\begin{tabular}{lccc}
\hline \multicolumn{1}{c}{ S. Typhimurium } & $\begin{array}{c}\text { Immunomagnetic } \\
\text { separation assay }\end{array}$ & Bacteriological & PCR \\
\hline $5 \mathrm{CFU} / 25 \mathrm{~mL}$ & 30 & 29 & 28 \\
$10 \mathrm{CFU} / 25 \mathrm{~mL}$ & 30 & 30 & 29 \\
$100 \mathrm{CFU} / 25 \mathrm{~mL}$ & 30 & 29 & 30 \\
Positive percentage & $100 \%$ & $97.7 \%$ & $96.6 \%$
\end{tabular}


in Rappaport-Vassiliadis broth (24 hours) done to improve the detection of positive samples, DNA extraction (1 hour), PCR (2 hours), and electrophoresis (40 minutes).

There were no statistically significant differences between the Salmonella serotype detection efficiencies of the bacteriophage-associated immunomagnetic separation assay, the bacteriological test, and the PCR-based test.

\section{DISCUSSION}

The development of rapid tests for improvement of pathogen-detection in food is essential to ensure food safety and to meet the growing demand for animal products, especially poultry meat and eggs. A literature review has shown that none of the commercial tests used for Salmonella diagnosis in poultry meet all the requirements, such as the detection limit (1 CFU/25g), time of analysis, sensibility and specificity, especially the analysis time (Eijkelkamp et al. 2009). Regarding the bacteriophage-associated immunomagnetic separation assay, we found a substantial reduction in the time required for obtaining the diagnostic results, even compared to the time needed for diagnosis by PCR.

This immunomagnetic separation assay was proposed by Favrin et al. (2001) wherein the lytic phage SJ2 is used for detection of Salmonella in broth. The test efficiently detected strains of $S$. Enteritidis. The main advantages of this method revealed by this trial were the speed, sensitivity, specificity, and ease of execution. In another experiment the authors employed the bacteriophage-associated immunomagnetic separation assay to detect $S$. Enteritidis and E. coli 0157:H7 in food samples. All foods contaminated with $S$. Enteritidis - which included skimmed milk powder, ground beef, and chicken - were detectable by the assay (Favrin et al. 2003).

In our study the bacteriophage P22 was chosen to perform the bacteriophage-associated immunomagnetic separation assay, because P22 presents lytic activity against different serovars of Salmonella, including $S$. Enteritidis, $S$. Typhimurium, and $S$. Heidelberg. This activity of the phage has been demonstrated in other tests used to detect the pathogen in food (Siqueira et al. 2003). The bacteriophage P22 recognizes the 0 -antigen lipopolysaccharide in the outer membrane of Salmonella serovars belonging to serogroups $\mathrm{A}, \mathrm{B}$, and $\mathrm{D}_{1}$ (Baxa et al. 1996). In the present study, we were able to verify the activity of P22 in three Salmonella serovars by employing the bacteriophage-associated immunomagnetic separation assay. Samples of $S$. Heidelberg and $S$. Typhimurium analyzed by bacteriophage-associated immunomagnetic separation assay tested positive at all the inoculum concentrations. However, one sample, with the lowest inoculum concentration (5 CFU/25mL) of $S$. Enteritidis, tested negative. These results demonstrate the test's ability to detect very low concentrations of Salmonella spp. in chicken rinses contaminated experimentally, as well as in the presence of bacterial competitive flora.

The research to discovery new lytic bacteriophages able to improve the immunomagnetic separation assay needs be continuous because our test is capable to detect only the three serovars most prevalent, but there are more than 2,600 Salmonella serovars. A viable option is prepared a bacteriophages cocktail (Marietto Gonçalves et al. 2014).

In the PCR-based test, all the inoculum concentrations of $S$. Heidelberg were detected; however, one sample of the Enteritis serovar tested negative at an inoculum concentration of $5 \mathrm{CFU} / 25 \mathrm{~mL}$. This is the same strain that was not detected in the bacteriophage-associated immunomagnetic separation assay. Using the PCR-based method for $S$. Typhimurium, 87 chicken rinses were deemed positive and three negative. Of the negative samples two were inoculated with the lowest concentration (5 CFU/25mL) and one was inoculated with $10 \mathrm{CFU} / 25 \mathrm{~mL}$. A study comparing the standard microbiological techniques and PCR-based method for detection of Salmonella spp., also found three samples negative for $S$. Typhimurium by PCR but positive by bacteriological testing. However, more number of positive samples were detected by PCR compared to bacteriological tests (Castagna et al. 2005). In a multicenter study, which was performed to validate the accuracy of PCR for Salmonella, some strains were undetectable (Malorny et al. 2003). This was attributed to a partial degradation of the DNA sample through DNase activity, since the extraction method used was heat treatment. We believe that the reasons for four samples testing negative by PCR in our study, were DNA degradation and the low concentration of the pathogen in the sample, given that three samples belonged to the lowest inoculum concentration $(5 \mathrm{CFU} / 25 \mathrm{~mL})$ and the middle concentration (10 CFU/25mL) category.

In the bacteriological test for $S$. Heidelberg only 81 samples (90\%) tested positive, while for both the serovars Typhimurium and Enteritidis the number of samples that tested positive was $88(97.7 \%)$. All negative samples in the bacteriological test were detected to be positive by PCR, as well as by the bacteriophage-associated immunomagnetic separation assay. A comparative study between PCR and bacteriological test for the detection of Salmonella in eggs has reported no statistical difference between the two methods (Flôres et al. 2001). Furthermore, compared to the bacteriological test, the PCR-based test was able to detect two samples more. Another study did a comparative analysis between PCR, enzyme-linked immunosorbent assay (ELISA), and standard bacteriological methods for detection of Salmonella serovars (Dickel et al. 2005). In this study, Salmonella was recovered from poultry meat in $56.67 \%$ samples by bacteriological methods, whereas ELISA and PCR detected Salmonella in $71 \%$ and $75 \%$ of the samples of poultry meat, respectively.

In our study, the bacteriophage-associated immunomagnetic separation assay showed the best results when analyzing the time that was required to obtain the final diagnostic result. This was approximately 19 hours, including the pre-enrichment stage, corroborating with another study (Favrin et al. 2003). However, other rapid tests using bacteriophages that did not include the pre-enrichment step, obtained results in 4 to 5 hours (Stewart et al. 1998, Favrin et al. 2001, Siqueira et al. 2003).

In our study, we included an enrichment step to avoid working with pure cultures that are not subjected to interference from competitive bacterial flora. This simulates the actual situation found in the routine bacteriological field samples received for analysis, which are mostly mixed bacterial flora and injured cells. If the sample presents low levels of contamination, it is necessary to include a pre-enrichment step in the tests, to recover the damaged cells and increase the bacterial concentration to detectable levels.

By PCR, we obtained the final diagnostic result in 44 hours. The inclusion of the selective enrichment step in Rappaport-Vassiliadis broth was necessary due to the low concentration of the Salmonella inoculum and the presence 
of competing bacteria in the samples. Some authors have reported that a limitation of PCR is the inhibition of the Taq polymerase by components present in food samples, as well as the presence of low numbers of target bacteria per gram of food (Saroj et al. 2008). The bacteriological test was the method with the longest analysis time, being 88 hours. The bacteriological assay is considered the gold standard for Salmonella detection in food samples. Each country follows its own standards and regulations for the isolation of this pathogen, for example, ISO 6579: 2002 (ISO 2002) or European gold standard (DIN EN 1998). However, the main steps for detection of Salmonella in food are chiefly the same: non-selective pre-enrichment, selective enrichment, isolation on selective solid agar, and the biochemical and serological confirmation. However, the experimental time spent varies: confirmation of a positive result following the ISO 6579 methodology 2002 can take up to six days, while using the methodology recommended by DIN EN 12824:1998, it is obtained in eight days (Schönenbrücher et al. 2008). However, negative results may be issued in four to six days.

\section{CONCLUSION}

We can conclude that the three tests show equivalence in relation to the detection of positive samples of Salmonella Enteritidis, $S$. Heidelberg, and $S$. Typhimurium in chicken rinses. However, the bacteriophage-associated immunomagnetic separation assay was the fastest method for detection of Salmonella, in about 19 hours, making it applicable for routine laboratory use as a screening test.

Conflict of interest statement.- The authors have no competing interests.

Acknowledgements.- We thank Foundation for Research State of São Paulo (FAPESP) for its financial support of the experiments through process 2013/04365-3, and CAPES for granting a doctoral scholarship to Isadora Mainieri de Oliveira Corrêa. Also we thank Keila Carolina O.D. Garcia for laboratorial support and article review.

\section{REFERENCES}

Alcocer I. \& Oliveira T.C.R.M. 2003. Detecção rápida de Salmonella Enteritidis em alimentos por ensaio imunoenzimático ELISA. Ciênc. Tecnol. Aliment. 23(3):401-408. <http://dx.doi.org/10.1590/S0101-20612003000300019>

Andrade R.B., Gemelli T., Dall Onder L.P., Cristina K., Brito T., Barboza A.A.L. \& Brito B.G. 2010. Métodos diagnósticos para os patógenos alimentares: Campylobacter sp., Salmonella sp. e Listeria monocytogenes. Arqs Inst. Biológico, São Paulo, 77:741-750.

Andreatti Filho R.L., Fernandes S.A., Boretti L.P., Barros M.R., Del Bem S.R., Fontana A., Sampaio H.M. \& Savano E.N. 2001. Sorovares de Salmonella isolados de materiais avícolas no período de 1994 a 1999. Revta Educ. Contin. 4:90-101.

Andreatti Filho R.L., Higgins J.P., Higgins S.E., Gaona G., Wolfenden A.D., Tellez G. \& Hargis B.M. 2007. Ability of bacteriophages isolated from different sources to reduce Salmonella enterica serovar Enteritidis in vitro and in vivo. Poult. Sci. 86(9):1904-1909. <http://dx.doi.org/10.1093/ps/86.9.1904> $<$ PMid:17704377>

Andreatti Filho R.L., Marietto Gonçalves G.A., Okamoto A.S. \& Lima E.T. 2011. Comparação de métodos para extração de DNA na reação em cadeia da polimerase para detecção de Salmonella enterica sorovar Enteritidis em produtos avícolas. Ciênc. Anim. Bras. 12(1):115-119. <http://dx.doi. org/10.5216/cab.v12i1.3774>
Baxa U., Steinbacher S., Miller S., Weintraub A., Huber R. \& Seckler R. 1996 Interactions of phage P22 tails with their cellular receptor, Salmonella O-Antigen polysaccharide. Biophys. J. 71(4):2040-2048. <http://dx.doi. org/10.1016/S0006-3495(96)79402-X><PMid:8889178>

Castagna S.M.F., Muller M., Macagnan M., Rodenbusch C.R., Canal C.W. \& Cardoso M. 2005. Detection of Salmonella sp. from porcine origin: a comparison between a PCR method and standard microbiological techniques. Braz. J. Microbiol. 36(4):373-377. <http://dx.doi.org/10.1590/ S1517-83822005000400013>

CDC 2014. Foodborne Diseases Active Surveillance Network: foodnet surveillance report for 2012 (final report). Centers for Disease Control and Prevention, Department of Health and Human Services, Atlanta, Georgia. Disponible at <http://www.cdc.gov/foodnet/PDFs/2012_annual_report_508c.pdf> Access on Jan. 15, 2017.

Dickel E.L., Rodrigues L.B., Santos L.R., Valle S.F., Pilotto F., Rodembush C., Wald V.B., Canal C.W. \& Nascimento V.P. 2005. Análise comparativa entre microbiologia convencional, ELISA e PCR para detecção de Salmonella enteritidis, $S$. typhimurium, $S$. gallinarum e $S$. pullorum em carne de frango contaminada artificialmente. Revta Bras. Ciênc. Vet. 12:5-10.

DIN EN 1998. Microbiology of food and animal feeding stuffs: horizontal method for the detection of salmonella (ISO 6579:1993, modified). DIN EN 12824:1998-02. Din, Berlin. 32p.

Donado-Godoy P., Clavijo V., León M., Tafur M.A., Gonzales S., Hume M., Alali W., Walls I., Lo Fo Wong D.M. \& Doyle M.P. 2012. Prevalence of Salmonella on retail broiler chicken meat carcasses in Colombia. J. Food. Protect. 75(6):1134-1138. <http://dx.doi.org/10.4315/0362-028X.JFP-11-513> <PMid:22691484>

Duarte D.A.M., Ribeiro A.R., Vasconcelos A.M.M., Santos S.B., Silva J.V.D., Andrade P.L.A. \& Falcão L.S.P.C.A. 2009. Occurrence of Salmonella spp. in broiler chicken carcasses and their susceptibility to antimicrobial agents. Braz. J. Microbiol. 40(3):569-573. <http://dx.doi.org/10.1590/S151783822009000300020><PMid:24031401>

Eijkelkamp J.M., Aarts H.J.M. \& van der Fels-Klerx H.J. 2009. Suitability of rapid detection methods for Salmonella in poultry slaughterhouses. Food Anal. Methods 2(1):1-13. <http://dx.doi.org/10.1007/s12161-008-9040-5>

Fadl A.A., Nguyen A.V. \& Khan M.I. 1995. Analysis of Salmonella enteritidis isolates by arbitrarily primed PCR. J. Clin. Microbiol. 33(4):987-989. $<$ PMid:7790473>

Favrin S.J., Jassim S.A. \& Griffiths M.W. 2001. Development and optimization of a novel Immunomagnetic Separation-Bacteriophage assay for detection of Salmonella enterica serovar Enteritidis in broth. Appl. Environ. Microbiol. 67(1):217-224. <http://dx.doi.org/10.1128/AEM.67.1.217-224.2001> $<$ PMid:11133448>

Favrin S.J., Jassim S.A. \& Griffiths M.W. 2003. Application of a novel Immunomagnetic Separation-Bacteriophage assay for the detection of Salmonella enteritidis and Escherichia coli 0157:H7 in food. Int. J. Food Microbiol. 85(1/2):63-71. <http://dx.doi.org/10.1016/S0168-1605(02)00483-X><PMid:12810271>

Flôres M.L., Nascimento V.P., Kader I.I.T.A., Cardoso M., Santos L.R., Lopes R.F.F., Wald V.B. \& Barbosa T.M.C. 2001. Análise da contaminação por Salmonella em ovos do tipo colonial através da reação em cadeia da polimerase. Ciência Rural 33(3):553-557. <http://dx.doi.org/10.1590/ S0103-84782003000300025>

García E. \& López R. 2002. Los bacteriófagos y sus productos génicos como agentes antimicrobianos. Revta Esp. Quimioter. 15:306-312.

Goodman L.A. 1964. Simultaneous confidence intervals for contrasts among multinomial populations. Ann. Math. Stat. 35(2):716-725. <http://dx.doi org/10.1214/aoms/1177703569>

ISO 2002. Microbiology of food and animal feeding stuffs: horizontal method for the detection of Salmonella spp. International Organization for Standardization 6579:2002. 27p. 
Malorny B., Hoorfar J., Bunge C. \& Helmuth R. 2003. Multicenter validation of the analytical accuracy of Salmonella PCR: towards an International Standard. Appl. Environ. Microbiol. 69(1):290-296. <http://dx.doi. org/10.1128/AEM.69.1.290-296.2003><PMid:12514007>

Marietto Gonçalves G.A., Lima E.T.L., Donato T.C., Rocha T.S., Cisneros Álvarez L.E., Sequeira J.L. \& Andreatti Filho R.L. 2011. Eradication of Salmonella Typhimurium in broiler chicks by combined use of P22 bacteriophage and probiotic. Microbiol. Res. 3(1):e2. <http://dx.doi.org/10.4081/mr.2011.e2>

Marietto-Gonçalves G.A., Donato T.C., Baptista A.A.S., Corrêa I.M.O., Garcia K.C.O.D. \& Andreatti Filho R.L. 2014. Bacteriophage-induced reduction in Salmonella Enteritidis counts in the crop of broiler chickens undergoing preslaughter feed withdrawal. Poult. Sci. 93(1):216-220. <http://dx.doi. org/10.3382/ps.2013-03360><PMid:24570442>

Medeiros M.A.N., Oliveira D.C.N., Rodriguez D.P. \& Freitas D.R.C. 2011. Prevalence and antimicrobial resistance of Salmonella in chicken carcasses at retail in 15 Brazilian cities. Revta Panam. Salud Publica 30(6):555-560. <http:// dx.doi.org/10.1590/S1020-49892011001200010><PMid:22358402>

Panec M. \& Katz D.S. 2006. Plaque Assay Protocols. ASM MicrobeLibrary. Disponible at <http://www.microbelibrary.org/component/resource/ laboratory-test/3073-plaque-assay-protocols> Access on Jan. 15, 2017.

Santos D.M.S., Berchieri Junior A., Fernandes S.A., Tavechio A.T. \& Amaral L.A. 2000. Salmonella em carcaças de frango congeladas. Pesq. Vet. Bras. 20(1):39-42.<http://dx.doi.org/10.1590/S0100-736X2000000100005>

Saroj S.D., Shashidhar R., Karani M. \& Bandekar J.R. 2008. Rapid, sensitive, and validated method for detection of Salmonella in food by an enrichment broth culture: nested PCR combination assay. Mol. Cell. Probes 22(3):201206. <http://dx.doi.org/10.1016/j.mcp.2008.02.002><PMid:18406104>
Scallan E., Hoekstra R.M., Angulo F.J., Tauxe R.V., Widdowson M.-A., Roy S.L., Jones J.L. \& Griffin P.M. 2011. Foodborne Illness Acquired in the United States: major pathogens. Emerg. Infect. Dis. 17(1):7-15. <PMid:21192848>

Schönenbrücher V., Mallinson E.T. \& Bülte M. 2008. A comparison of standard cultural methods for the detection of foodborne Salmonella species including three new chromogenic plating media. Int. J. Food Microbiol. 123(1/2):61-66. <http://dx.doi.org/10.1016/j.ijfoodmicro.2007.11.064> $<$ PMid:18192050>

Siqueira R.S., Dodd C.E.R. \& Rees C.E.D. 2003. Phage amplification assay as rapid method for Salmonella detection. Braz. J. Microbiol. 34:118-120. <http://dx.doi.org/10.1590/S1517-83822003000500040>

Stewart G.S.A.B., Jassim S.A.A., Denyer S.P., Newby P., Linley K. \& Dhir V.K. 1998. The specific and sensitive detection of bacterial pathogens within $4 \mathrm{~h}$ using bacteriophage amplification. J. Appl. Microbiol. 84(5):777-783. <http://dx.doi.org/10.1046/j.1365-2672.1998.00408.x><PMid:9674131>

Swamy S.C., Barnhart H.M., Lee M.D. \& Dreesen D.W. 1996. Virulence determinants invA and spvC in Salmonellae isolated from poultry products, wastewater, and human sources. Appl. Environ. Microbiol. 62(10):37683771. <PMid:8837432>

Tessari E.N.C., Cardoso A.L.S.P., Kanashiro A.M.I., Stoppa G.F.Z., Luciano R.L. \& Castro A.G.M. 2008. Ocorrência de Salmonella spp. em carcaças de frangos industrialmente processadas, procedentes de explorações industriais do Estado de São Paulo, Brasil. Ciência Rural 38(9):2557-2560. <http:// dx.doi.org/10.1590/S0103-84782008000900023>

Zhao C., Ge B., de Villena J., Sudler R., Yeh E., Zhao S., White D.G., Wagner D. \& Meng J. 2001. Prevalence of Campylobacter spp., Escherichia coli, and Salmonella serovars in retail chicken, turkey, pork, and beef from the greater Washington, D.C. area. Appl. Environ. Microbiol. 67(12):5431-5436. <http:// dx.doi.org/10.1128/AEM.67.12.5431-5436.2001><PMid:11722889> 